\title{
GENETIC POLYMORPHISM OF BLOOD PROTEINS IN YUGOSLAV SHEPHERD DOG
}

\author{
DIMITRIJEVIĆ V, JOVANOVIĆ S, SAVIĆ MILA and TRAILOVIĆ RUŽICA \\ Faculty of Veterinary Medicine, Belgrade \\ (Received 5. May 2005)
}

The present study is aimed to provide the first insight into the genetic constitution of Yugoslav shepherd dog based upon analysis of blood proteins and enzyme polymorphism. A total of 60 Yugoslav shepherd dogs were included in the study and polymorphism of hemoglobin (Hb), acid phosphatase (Acp), superoxide dismutase (Sod), albumin (Al), and transferrine (Tf) was electrophoretically analysed. Hb system did not show polymorphism. FS and SS phenotypes of $A c p$ were established with $A c P^{S}$ allelic gene displaying significantly higher frequency (0.82) than $A c P^{\mathrm{F}}(0.18)$. The analysis of Sod polymorphism showed SodAA and SodAB phenotypes controlled by Sod ${ }^{\mathrm{A}}(0.74)$ and $\operatorname{Sod}^{\mathrm{B}}(0.26)$ with clear predominance of $\operatorname{Sod}^{\mathrm{A}}$ allele. Both Al allelic genes, $A I^{F}(0.30)$ and $A l^{S}(0.70)$, and all three possible phenotypes ( $F, F S$, and $S)$ were detected. Seven Tf phenotypes controlled by five allelic genes $T f^{\mathrm{A}}, T f^{\mathrm{B}}, T f^{\mathrm{C}}, T f^{\mathrm{D}}$, and $T f^{\mathrm{E}}$ were revealed which makes the Yugoslav shepherd dog the only dog breed displaying all five $\mathrm{Tf}$ genes. The associated gene frequences were $(0.13,0.35$, $0.06,0.41 \mathrm{i}$ 0.05), respectively. According to the calculated values of homogeneity index, Al and Tf were identyfied as highly polymorphic protein markers which is a result of importance for future genetic characterization of the Yugoslav shepherd dog. Significant deviations from Hardy-Weinberg equilibrium were detected at Sod and Tf loci, these being primarily attributed to genetic drift, although crossbreeding should not be disregarded as a factor of possible importance as well. dog

Key words: protein, polymorphism, genome, Yugoslav shepherd

\section{INTRODUCTION}

Studies focused on the genetic characterization of species and breeds of domestic animals have a wide range of possible applications. These studies have been carried out to investigate the origin and course of domestication of different species and breeds (Braend and Roed, 1987; Tanabe, 1990; Troy, 2001; Savolainen et al, 2002), to characterize the breeds and lines (by estimation of genetic drift and distance) (Pihkanen et al, 1996; Tsuda et al, 1997), to design adequate breeding programs based upon the identification of genes which 
control economically relevant traits (Christensen et al, 1985; Andersson et al, 1987), for parentage control (Juneja et al,1987; Dostal and Stratil, 1994; Garcia et al, 2002), etc. Genetic characterization of autochthonous breeds in different geographical localities is of particular importance. Some autochthonous breeds of sheep (Jovanović et al, 1988), pigs (Jovanović, 1982), goats (Savić et al, 1995), and horses (Trailović et al, 1994) in our country have already been genetically characterized based upon analysis of protein polymorphism. To date, however, no analysis of the genetics of autochthonous dog breeds in the region has been undertaken.

The Yugoslav shepherd dog is believed to be between $1600-2200$ years old and, thus, is considered as the oldest autochthonous dog breed in the Balkan peninsula (Dimitrijević, 1997). The breed was recognised by the F.C.I (Federation Cynologique Internationale) in 1939 under the name Illyrian Shepherd dog. In 1957, at the request of JKS (Yugoslav association), F.C.I. accepted to change the name into Yugoslav shepherd dog - Šarplaninac after the Šarplanina Mountain Range, where it is most common. Two countries, Serbia and Macedonia, are currently listed as countries of origin of this breed by the F.C.I. The exact ancestors and the origin of the Yugolsav shepherd dog still remain controversial. Great Tibetan Mastiff, ancient moloscian dogs of Greece, ancient roman dogs, and the livestock guarding dogs of Turkey have all been suggested as possible ancestors for the Yugoslav shepherd dog. It seems likely that the dogs of this breed had come from Asia to Europe and the Balkans, alongside the cattle herded by the migrating people. Upon arrival to the Balkans, these dogs maintained their existence and developed as a breed in the specific settings of Šarplanina, Korab, Jablanica and Pelister. The original breed type has been maintained in these regions, where extensive sheep breeding is still prevalent, with this dog as an irreplaceable herding dog and protector of sheep herds against predatory animals.

The aim of this study was to provide the first insight into the genetic constitution of the Yugoslav shepherd dog based upon analysis of blood proteins and enzyme polymorphism.

\section{MATERIAL AND METHODS}

\section{Study population}

A total of 60 Yugoslav shepherd dogs were used in this study. All dogs were bred in the Center for Dog Breeding, Niš.

\section{Blood samples collection}

Blood samples $(10 \mathrm{ml})$ with EDTA were collected by venipuncture of v. cephalicae antebrachii. Plasma and erythrocytes were separated by centrifugation at $3500 \mathrm{rpm}$ over 10 minutes. Subsequently, the red cells were washed three times in physiological saline and hemolyzed by adding an equal volume of distilled water. All samples were stored at $-20^{\circ} \mathrm{C}$ until electrophoretical investigation. 


\section{Analysis of protein polymorphism}

For the purposes of genetic characterization of the Yugoslav shepherd dog, polymorphism of the following five blood proteins and enzymes was analyzed: hemoglobin ( $\mathrm{Hb}$ ), acid phosphatase (Acp), superoxide dismutaze (Sod), albumin (Al), and transferrine (Tf). The Hb, Acp, and Sod types were analyzed by vertical polyacrylamide gel electrophoresis (PAGE) in discontinuous tris-citrate buffer system, while vertical PAGE in continuous tris-citrate buffer system was used for detection of $\mathrm{Al}$ and $\mathrm{Tf}$ polymorphism (Pasteur et al, 1988). Considering that $\mathrm{Hb}$ is a stained protein, no specific staining technique was required for analysis of HB types. Detection of Sod types was achieved by nitroblue tetrazolium stain (BioRad Laboratories, USA) in accordance to the method of Beakchamp and Fridovich (1971). The Acp, Al, and Tf gels were stained by coomassie blue R-250 (Bio-Rad Laboratories, USA) (Pasteur et al, 1988).

\section{Statistical analyses}

Gene frequencies were established by direct counting from the phenotypes and the homogeneity index was calculated. In order to assess the genetic equilibrium in the study population, Hardy-Weinberg equilibrium was performed on phenotypes deduced from the counted gene frequencies. The differences between phenotype frequencies expected in accordance with Hardy-Weinberg equilibrium and those observed in the study population were evaluated by ${ }^{2}$ test. $p$ values that were less than 0.05 were considered significant.

\section{RESULTS AND DISCUSSION}

\section{Hb polymorphism}

Evaluation of $\mathrm{Hb}$ polymorphism in blood of the Yugoslav shepherd dog revealed only one allelic product, namely phenotype B. The phenotype is characterized by the presence of two bands and presents the phenotypic expression of HbBB homozygous type. The obtained results are consistent with the results of previous studies since $\mathrm{Hb}$ locus did not show polymorphism in any of European breeds tested, nor in the majority of oriental dog breeds (Simonsen, 1976; Braend, 1987). Additional two $\mathrm{Hb}$ phenotypes, namely $A$ and $A B$ phenotypes, were established only in Japanese native dog breeds (Tanabe et al, 1978). Quite understandably, the gene frequency established for the population of Yugoslav shepherd dog was identical to gene frequencies established in the previously examined European and oriental dog breeds. As already noted, Japanese native breeds did not correspond to this uniform distribution (Tanabe et al, 1978) since frequency of allelic gene $\mathrm{Hb}^{\mathrm{A}}$ in these breeds ranged from 0.000 (Shikoku) to 0.290 (San'in-Shiba). This discrepancy is primarily attributed to the specific genetic background of these breeds (Tanabe et al, 1991), which most probably includes the influence of genes originating from an ancestral dog line brought from the Korean peninsula. It is noteworthy that similar inconsistencies have already been noted in Japanese native breeds for other loci, such as Acp ${ }^{F}$ and $\mathrm{Al}^{\mathrm{S}}$ (Tanabe, 1990; Tanabe et al, 1991). The overall data show that the results 
of our survey are in agreement with the results of other studies investigating $\mathrm{Hb}$ polymorphism in various dog breeds and they provide support for the presumed Eurasian origin of the Yugoslav shepherd dog.

\section{Acp polymorphism}

The analysis of erythrocyte Acp in the Yugoslav shepherd dog detected only two of the expected three (FF, FS, and SS) phenotypes. Homozygous form AcpFF was not established within the studied population. Acp ${ }^{S}$ allelic gene displayed a significantly higher frequency than Acp ${ }^{F}$ (Table 1) which has also been shown in other dog breeds (Braend and Austad, 1973; Elliot and Wong, 1973). Although the values of gene frequencies established in different studies were similar, there is a difference among phenotype distribution patterns. Two distinct phenotypes, FS and SS were found in the population of Yugoslav shepherd dog. All three theoretically possible phenotypes (FF, FS, and SS) were observed only in the breed Labrador retriever, while examination of German shepherd and German pointer revealed only one phenotype, namely SS (Braend and Austad, 1973). It is interesting to note that the study concerning biochemical genetic variability in race hounds did not establish any biochemical variation in Acp (Scherer and Kluge, 1993).

Table 1. Gene frequencies and observed vs. expected acid phosphatase phenotypes ratio in Yugoslav shepherd dog

\begin{tabular}{|c|c|c|c|c|c|c|}
\hline $\begin{array}{c}\text { Number of } \\
\text { animals }\end{array}$ & \multicolumn{5}{|c|}{ Acp phenotypes } & \multicolumn{2}{c|}{ Gene frequency } \\
\hline \hline \multirow{3}{*}{60} & & FF & FS & SS & Acp F & Acp $^{S}$ \\
\cline { 2 - 7 } & observed & 0 & 22 & 38 & 0.18 & 0.82 \\
\cline { 2 - 7 } & expected & 2 & 17.94 & 40.06 & & \\
\hline \multicolumn{7}{|c|}{$2=3.0247(\mathrm{p}>0.05)$} \\
\hline
\end{tabular}

Acp $=$ acid phosphatase

\section{Sod polymorphism}

Analysis of Sod polymorphism in the Yugoslav shepherd dog showed two distinct phenotypes, homozygous SodAA and heterozygous SodAB, controlled by allelic genes $\operatorname{Sod}^{A}$ and $\operatorname{Sod}^{B}$ (Table 2). The SodBB phenotype was not found in the tested population. The obtained results support the findings of all previous studies which established a low Sod ${ }^{\mathrm{B}}$ frequency (Muller et al, 1987; Scherer and Kluge, 1993) since a clear predomination of Sod ${ }^{A}$ allele was seen in the studied population. It should be noted, however, that $\mathrm{Sod}^{\mathrm{B}}$ allele frequency established in Yugoslav shepherd dog of 0.258 was higher than those of the allelic gene found in other tested dog breeds. Values of all $\mathrm{Sod}^{\mathrm{B}}$ allele frequencies reported so far remained below 0.1 (Muller et al, 1987; Scherer and Kluge, 1993). The most probable explanation for high level of Sod ${ }^{\mathrm{B}}$ occurrence in the tested population is genetic drift. It seems reasonable to assume that intensive breeding within a 
Acta Veterinaria (Beograd), Vol. 55. No. 5-6, 357-365, 2005.

Dimitrijević $\mathrm{V}$ et al. Genetic polymorphism of blood proteins in Yugoslav shepherd dog

limited area and population resulted in unbalanced distribution of SodB allele originating from a relatively small number of males widely used as sires.

Table 2. Gene frequencies and observed vs. expected superoxide dismutaze phenotypes ratio in Yugoslav shepherd dog

\begin{tabular}{|c|c|c|c|c|c|c|}
\hline $\begin{array}{c}\text { Number of } \\
\text { animals }\end{array}$ & \multicolumn{5}{|c|}{ Sod phenotypes } & \multicolumn{2}{c|}{ Gene frequency } \\
\hline \hline \multirow{3}{*}{60} & & AA & AB & BB & Sod $^{A}$ & Sod $^{B}$ \\
\cline { 2 - 7 } & observed & 29 & 31 & 0 & 0.74 & 0.26 \\
\cline { 2 - 7 } & expected & 33 & 23 & 4 & & \\
\hline \multicolumn{6}{|c|}{$2=7.2674(\mathrm{p}<0.05)$} \\
\hline
\end{tabular}

Sod $=$ superoxide dismutase

\section{Al polymorphism}

As far as polymorphism of $\mathrm{Al}$ is concerned, both allelic genes described so far, $\left(\mathrm{Al}^{\mathrm{F}}\right.$ and $\mathrm{Al}^{\mathrm{S}}$ ) as well as all three theoretically possible phenotypes (F, FS, and S), were detected in Yugoslav shepherd dog (Table 3). Al has been established as a reliable marker in biochemical genetic variability studies due to its wide distribution and intermediate frequencies displayed by $\mathrm{Al}^{\mathrm{F}}$ and $\mathrm{Al}^{\mathrm{S}}$ allelic genes (Christensen et al, 1985; Scherer and Kluge, 1993). The ratio between $\mathrm{Al}^{\mathrm{F}}$ and $\mathrm{Al}^{\mathrm{S}}$ frequencies established in the population of Yugoslav shepherd dog is consistent with results of the study which found a linkage between Al type and leg length (Christensen et al, 1985). A higher frequency of the $\mathrm{Al}^{\mathrm{F}}$ allele in short-legged breeds and predominance of the $\mathrm{Al}^{\mathrm{S}}$ allele in long-legged breeds documented it. $\mathrm{Al}^{\mathrm{S}}$ frequency ranged from 0.560 in German shepherd dog to 1.000 in the German Dane, Basenji and Siberian husky (Christensen et al, 1985). In contrast to these findings, the study investigating protein polymorphism in race hounds did not establish the correlation between Al type and leg length (Scherer and Kluge, 1993). Given the $\mathrm{Al}^{\mathrm{S}}$ frequency of 0.700 established in the Yugoslav shepherd dog, the results of the present study strongly support the hypothesis on the positive correlation between $\mathrm{Al}^{\mathrm{S}}$ frequency and leg length.

Table 3. Gene frequencies and observed vs. expected albumin phenotypes ratio in Yugoslav shepherd dog

\begin{tabular}{|c|c|c|c|c|c|c|}
\hline $\begin{array}{c}\text { Number of } \\
\text { animals }\end{array}$ & \multicolumn{5}{|c|}{ Al phenotypes } & \multicolumn{2}{c|}{ Gene frequency } \\
\hline \hline \multirow{3}{*}{60} & & FF & FS & SS & $\mathrm{Al}^{\mathrm{F}}$ & $\mathrm{Al}^{\mathrm{S}}$ \\
\cline { 2 - 7 } & observed & 7 & 22 & 31 & 0.30 & 0.70 \\
\cline { 2 - 7 } & expected & 5.4 & 25.2 & 29.4 & & \\
\hline \multicolumn{7}{|c|}{$20.9675(\mathrm{p}>0.05)$} \\
\hline
\end{tabular}

$\mathrm{Al}=$ albumin 


\section{Tf polymorphism}

The evaluation of the Tf locus revealed seven of 15 theoretically possible Tf phenotypes, which are controlled by five allelic genes: $\mathrm{Tf}^{\mathrm{A}}, \mathrm{Tf}^{\mathrm{B}}$, $\mathrm{Tf}^{\mathrm{C}}, \mathrm{Tf}^{\mathrm{D}}$, and $\mathrm{Tf}^{\mathrm{E}}$. The distribution of Tf phenotypes and calculated gene frequencies are shown in Table 4. Out of the 60 dogs tested, 35 (58.33\%) had heterozygous BD phenotype, while a significantly lower number of animals, 12 (20\%), displayed heterozygous $A D$ phenotype. The proportion of BB homozygotes and CE heterozygotes of $1.66 \%$ was the lowest established within the population studied. Tf along with aryl esterase and $\mathrm{C} 6$ and $\mathrm{C} 4$ complement components belong to the category of most complex and polymorphic biochemical markers of genetic variability in dogs. The majority of earlier studies have reported the presence of three most frequent allelic genes, $\mathrm{Tf}^{\mathrm{A}}$, $\mathrm{Tf}^{\mathrm{B}}$, and $\mathrm{Tf}^{\mathrm{C}}$ within the various populations tested (Komatsuzaki, 1983; Braend and Andersen, 1987). Only Juneja et al (1981) and Tanabe (1990) proved all five Tf allelic genes, but not within one dog breed. Yugoslav shepherd dog is the only dog breed which displayed all five Tf loci and thus exhibited the maximal polymorphism of this highly heterogeneous marker. In addition, a specific distribution of allelic gene frequencies was also established within the observed population. In the majority of other examined dog breeds, allelic genes $\mathrm{Tf}^{\mathrm{B}}$ and $\mathrm{Tf}^{\mathrm{C}}$ were found to appear most frequently (Juneja et al, 1981; Komatsuzaki, 1983; Braend and Andersen, 1987; Tanabe, 1990). In contrast to these studies, the highest gene frequencies were registered for allelic genes $\mathrm{Tf}^{\mathrm{B}}$ and $\mathrm{Tf}^{\mathrm{D}}$ within the studied population of the Yugoslav shepherd dog. We presume that this discrepancy is most probably related to genetic drift i.e. to specific breeding of Yugoslav shepherd dog within a restricted area where this breed has differentiated over the centuries.

Table 4. Gene frequencies and observed vs. expected transferrin phenotypes ratio in Yugoslav shepherd dog

\begin{tabular}{|c|c|c|c|c|c|}
\hline \multirow{2}{*}{$\begin{array}{l}\text { Number of } \\
\text { animals }\end{array}$} & \multirow{2}{*}{ Phenotypes } & \multirow{2}{*}{ Observed } & \multirow{2}{*}{ Expected } & \multicolumn{2}{|c|}{ Gene frequency } \\
\hline & & & & Allele & Frequency \\
\hline \multirow{15}{*}{60} & AA & 0 & 1.06 & $\mathrm{Tf}^{\mathrm{A}}$ & 0.13 \\
\hline & BB & 1 & 7.35 & $\mathrm{Tf}^{\mathrm{B}}$ & 0.35 \\
\hline & $\mathrm{CC}$ & 0 & 0.21 & $\mathrm{Tf}^{\mathrm{C}}$ & 0.06 \\
\hline & DD & 0 & 9.99 & $\mathrm{Tf}^{\mathrm{D}}$ & 0.41 \\
\hline & EE & 0 & 0.15 & $\mathrm{Tf}^{\mathrm{E}}$ & 0.05 \\
\hline & $A B$ & 0 & 5.59 & & \\
\hline & $A C$ & 4 & 0.94 & & \\
\hline & $A D$ & 12 & 6.51 & & \\
\hline & $\mathrm{AE}$ & 0 & 0.8 & & \\
\hline & $B C$ & 0 & 2.48 & & \\
\hline & $\mathrm{BD}$ & 35 & 17.14 & & \\
\hline & $\mathrm{BE}$ & 5 & 2.1 & & \\
\hline & $\mathrm{CD}$ & 2 & 2.88 & & \\
\hline & CE & 1 & 0.35 & & \\
\hline & $\mathrm{DE}$ & 0 & 2.45 & & \\
\hline \multicolumn{6}{|c|}{$2=66.8981(p<0.01)$} \\
\hline
\end{tabular}

$\mathrm{Tf}=$ transferrin 
Homogeneity index for Sod, Acp, Al, and Tf loci was calculated upon the number of established allelic genes for each locus and the corresponding gene frequencies (Table 5). Homogeneity index for $\mathrm{Hb}$ locus was not evaluated since the present study showed only one homozygous form of this protein in the Yugoslav shepherd dog. Out of four loci, which showed polymorphism in the studied population, the highest homogeneity index was established for Acp locus. Values of homogeneity indices for Al and Tf loci were significantly lower. Thus, protein markers displaying high polymorphism in the Yugoslav shepherd dog were identified, this provides guidelines for future biochemical genetic variability investigation in this breed.

Table 5. Homogeneity index for superoxide dismutase, acid phosphatase, albumin, and The homogeneity index (HI) was calculated transferrin loci in Yugoslav shepherd dog

\begin{tabular}{|c|c|c|c|c|}
\hline Locus & Sod & Acp & Al & Tf \\
\hline \hline Number of alleles & 2 & 2 & 2 & 5 \\
\hline Homogeneity index & 0.2344 & 0.4020 & 0.1600 & 0.1409 \\
\hline
\end{tabular}

Sod $=$ superoxid dismutase; $\mathrm{Acp}=$ acid phosphatase $; \mathrm{Al}=$ albumin; $\mathrm{Tf}=$ transferrin

Upon the calculated allelic frequencies it was shown that the population of Yugoslav shepherd dog was in genetic equilibrium at $\mathrm{Hb}, \mathrm{Acp}$, and $\mathrm{Al}$ loci, while significant deviations from Hardy-Weinberg equilibrium were detected at Sod and Tf loci. The established imbalance to Hardy-Weinberg law at these two loci may be attributed to genetic drift, mutation, migration or crossbreeding. As already stated, we presume that the most prominent factor affecting genetic equilibrium was genetic drift. It is noteworthy, however, that crossbreeding of the Yugoslav shepherd dog with various dog breeds has become a common breeding practice over the last decades and, therefore, should also be considered as a factor of possible importance. Such mixing may lead to a serious disbalance in the genetic constitution of the breed, outbreed depression, and deprivation of major biological features of the breed.

Our study provided the first insight into the genetic structure of the Yugoslav shepherd dog and enabled comparison of the genetic constitution of this breed with dog breeds which have already been genetically characterized. In order to preserve the endogenous genetic pool and original characteristics of the Yugoslav shepherd dog, and to assess the possibly detrimental effects of crossbreeding which has already been undertaken, further investigation into genetic structure of this breed based upon molecular techniques is currently underway in our laboratory.

Address for correspondence:

Vladimir Dimitrijević

Department of Animal Breeding and Genetics

Faculty of Veterinary Medicine, University of Belgrade

Bulevar oslobođenja 18,

11000 Belgrade, Serbia \& Montenegro

E-mail: vanja@vet.bg.ac.yu 


\section{REFERENCES}

1. Andersson L, Arnason T, Sandberg K, 1987, Biochemical polymorphism in relation to performance in horses. Theoretical App/ Genet, 73, 419-27.

2. Beakchamp C, Fridovich J, 1971, Superoxide dismutase: improved assays and an assay applicable to acrilamide gels. Anal Biochem, 44, 276-86.

3. Braend M, 1987, Hemoglobin polymorphism in the domestic dog. J Hered, 79, 211-12.

4. Braend M, Andersen AE, 1987, Variation of transferrin and esterase in sera of dogs. Acta Vet Scand, 28, 435-44.

5. Braend M, Austad R, 1973, Polymorphism of red cell acid phosphatase in dogs. Anim Blood Groups Biochem Genet, 4, 189-92.

6. Braend M, Roed $\mathrm{KH}, 1987$, Polymorphism of transferrin and esterase in Alaskan wolves: evidence of close molecular homology with the dog. Anim Genet, 18, 143-9.

7. Christensen K, Arnbjerg J, Andresen E, 1985, Polymorphism of serum albumin in dog breeds and its relation to weight and leg length. Hereditas, 102, 219-23.

8. Dimitrijević V, 1997, Stanje i pravci u selekciji jugoslovenskog ovčarskog psa. Savremena Poljoprivreda, XX 3-4, 199-203.

9. Dostal J, Stratil A, 1994, Polymorphic markers as tools for paternity control in dogs. XXIV International Conference on Animal Genetics, 23. - 29. 07., Prague. Abstract book B 14.

10. Elliot O, Wong M, 1972, Acid phosphatase, handy enzyme that separates the dog from the wolf. Acta Biol Med Ger, 28, 957-62.

11. Garcia D, Carleos C, Parra D, Canon J, 2002, Sib-parentage testing using molecular markers when parents are unknown. Anim Genet, 33, 364-71.

12. Jovanović $S, 1982$, Polimorfizam nekih proteina krvnog seruma jugoslovenske mesnate svinje. Doktorska disertacija, Veterinarski fakultet, Univerzitet u Beogradu.

13. Jovanović S, Reljić M, Adžić N, 1988, Proučavanje uticaja tipa hemoglobina na sposobnost adaptacije i neka reproduktivna svojstva ovaca. XII savetovanje o dijagnostici, profilaksi $i$ terapiji u savremenoj stočarskoj proizvodnji, Primošten. Zbornik radova.

14. Juneja RK, Andersen AE, Christensen K, Gahne B, 1981, Frequencies of transferrin types in various breeds of domestic dogs. Anim Blood Groups Biochem Genet, 12, 79-88.

15. Juneja RK, Arnold ICJ, Gahne B, Bouw J, 1987, Parentage testing of dogs using variants of blood proteins: description of five new plasma protein polymorphisms. Anim Genet 18, 297-310.

16. Komatsuzaki T, 1983, Genetic polymorphism of plasma proteins in Beagles. Bulletin of Azabu University, Veterinary Medicine, 4, 141-8.

17. Muller S, Spadiut U, Schleger W, 1987, Genetic marker in austrian dogs. Anim Genet 18(suppl 1), 65-9.

18. Pasteur N, Pasteur C, Bonhomme F, Katalan J, Britton-Davidian J, 1988, Practical isozymes genetics, Ellis Horwood Limited.

19. Pihkanen S, Vainola R, Varvio S, 1996, Characterization of dog breed differentiation with microsatellite markers. Anim Genet, 27, 343-6.

20. Savić M, Jovanović S, Trailović $R, 1995$, Some genetic markers in the blood of the Balkan goat. Acta Veterinaria, 5-6, 299-302.

21. Savolainen P, Zhang Y, Luo J, Lundeberg J, Lettner T, 2002, Genetic evidence for an East Asian origin of domestic dogs. Science, 298, 1610-3.

22. Scherer K, Kluge $R, 1993$, Biochemical variation of blood proteins in race hounds. $J$ Vet Med, 40, 169-77.

23. Simonsen V, 1976, Electrophoretic studies on the blood proteins of domestic dogs and other Canidae. Hereditas, 82, 7-17.

24. Tanabe Y, 1990, Genetic relationships among dog breeds with special reference to Asian dog breeds studied by biochemical polymorphism of blood proteins. Prog Clin Biol Res, 344, 61937.

25. Tanabe $Y$, Ota K, Ito $S$, 1991, Biochemical-genetic relationships among Asian and European dogs and the ancestry of the Japanese native dog. J Anim Breed Genet, 108, 455-78. 
26. Tanabe Y, Tokiyoshi O, Ota K, 1978, Genetic variants of hemoglobin in canine erythrocytes. Anim Blood Groups Biochem Genet, 9, 79-85.

27. Trailović $R$, Jovanović S, Savić $M, 1994$, Efficiency of some serum protein systems in parentage control in Yugoslav trotter horses. Acta Veterinaria, 4, 233-8.

28. Troy CS, MacHugh DE, Bailey JF, Magee DA, Loftus RT, Cunningham P, et al, 2001, Genetic evidence for Near-Eastern origins of European cattle. Nature, 410, 1088-91.

29. Tsuda K, Kikkawa Y, Yonekawa H, Tanabe Y, 1997, Extensive interbreeding occurred among multiple matriarchal ancestors during the domestication of dogs: evidence from inter- and intraspecies polymorphisms in the D-loop region of mitochondrial DNA between dogs and wolves. Genes Genet Syst, 72, 229-83.

\title{
GENETSKI POLIMORFIZAM PROTEINA U KRVI PASA RASE JUGOSLOVENSKI OVČARSKI PAS
}

\author{
DIMITRIJEVIĆ V, JOVANOVIĆ S, SAVIĆ MILA i TRAILOVIĆ RUŽICA
}

\section{SADRŽAJ}

Ova studija predstavlja prvu analizu genetske konstitucije pasa rase jugoslovenski ovčarski pas - šarplaninac na osnovu ispitivanja polimorfizma proteinskih i enzimskih sistema u krvi pasa ove rase. U studiju je bilo uključeno 60 pasa kod kojih je izvršena elektroforetska analiza polimorfizma hemoglobina $(\mathrm{Hb})$, eritrocitne kisele fosfataze (Acp), superoksid-dismutaze (Sod), albumina (Al) i transferina (Tf). U sistemu Hb nije ustanovljen polimorfizam. Dokazano je prisustvo FS i SS fenotipova Acp pri čemu je učestalost $A c p^{S}(0.82)$ alela u odnosu na $A c p F$ alel (0.18), bila značajno veća. Analizom polimorfizma Sod utvrđeni su SodAA i SodAB fenotipovi koji su kontrolisani Sod ${ }^{A}$ i Sod ${ }^{B}$ alelnim genima, sa frekvencama (0.74 i 0.26) prema redosledu, uz jasnu predominaciju $\operatorname{Sod}^{A}$ alela. $U$ ispitivanoj populaciji dokazano je prisustvo oba do sada opisana $A$ lalelna gena $\left(\mathrm{Al}^{\mathrm{F}} \mathrm{i} \mathrm{Al}^{\mathrm{S}}\right)$ sa frekvencama (0.30. i 0.70) kao i sva tri moguća fenotipa (F, FS i S). Utvrđeno je prisustvo sedam Tf fenotipova koje kontroliše pet alelnih gena, $\mathrm{Tf}^{\mathrm{A}}, \mathrm{Tf}^{\mathrm{B}}, \mathrm{Tf}^{\mathrm{C}}, \mathrm{Tf}^{\mathrm{D}} \mathrm{i}$ $\mathrm{Tf}^{\mathrm{E}}$ sa frekvencama $(0.13,0.35,0.06,0.41 \mathrm{i} 0.05)$ prema redosledu. Jugoslovenski ovčarski pas je jedina rasa pasa kod koje je ustanovljeno svih pet Tf alelnih gena pri čemu su najviše frekvence registrovane za alele $\mathrm{Tf}^{\mathrm{B}} \mathrm{i} \mathrm{Tf}^{\mathrm{D}}$. Na osnovu izračunatih vrednosti indeksa homogenosti, ustanovljeni su izrazito polimorfni proteinski markeri što je od značaja za buduće studije genetske karakterizacije jugoslovenskog ovčarskog psa. Dokazano je da se ispitivana populacija pasa u odnosu na Sod i Tf lokus ne nalazi u genetičkoj ravnoteži. Faktor koji je primarno uticao na stanje genetičke ravnoteže je genetički drift, ali je i ukrštanje faktor od potencijalno velikog značaja. 